\title{
Vivipary, Proliferation, and Phyllody in \\ Grasses
}

\section{A.A. BEETLE}

\begin{abstract}
Some temperate grasses have the ability to produce in their inflorescence modified spikelet structures that act to reproduce the species vegetatively. These types may be either genetically fixed or an occasional expression of environmental change.
\end{abstract}

Vivipary sometimes refers to the development of separable vegetative shoots, as in the case of Poa bulbosa, wherein florets have been transformed into bulbils. At other times vivipary refers to the germination of an embryo in situ before the fall of the seed, as in Melocalamus, the fleshy seeded bamboo from Burma.

Vegetative proliferation refers to the conversion of the spikelet, above the glumes, into a leafy shoot. These leafy shoots are not usually an effective method of reproduction in the wild, but are somewhat easier to establish under controlled conditions.

Both vivipary and proliferation may produce conspicuously abnormal spikelets which the latin words vivipara and prolifera have been used to describe, usually without any further discrimination than to indicate their presence. Sometimes the enlarged lemmas are sufficiently similar to leaves to differentiate blade from sheath with a prominent collar and ligule, referred to as phyllody (the metamorphosis of spikelet bracts, glumes, lemmas or paleas, into leaves). An alternate spelling "filodia" was used by Martinez (1945) when reporting cases in Cynosurus echinatus and Eragrostis virescens. Glumes are much more stable than lemmas and paleas. The glumes usually remain unchanged but may occasionally become foliage leaves (Wycherley 1953). The lemma is usually present and altered (always enlarged and never reduced). Paleas are often reduced or absent. Stamens and pistils are also reduced or absent.

According to the literature there are many causes of vivipary, proliferation, and phyllody in grasses:

(1) hereditary genes

(a) resulting in viviparous races

(b) hybridization

(c) polyploidy

(2) malformation (teratology)

(a) caused by mechanical injury

(b) caused by insects, nematodes, etc.

(c) caused by fungi, etc.

(3) adverse environmental factors, any of which may lead to a hormonal imbalance which results in ephemeral proliferation; Wycherley (1954) supposes that in the viviparous races a considerably greater minimal concen-

Author is professor, Range Management Division, University of Wyoming 82070 . Manuscript received October 16, 1978. tration of the putative flowering hormone is required for flower induction, whereas in the seminiferous races this difference is not so great. In the viviparous races, the threshold for flower initiation is rarely exceeded so that perfect flowers appear only occasionally, while in the normally seminiferous races, the conditions arise only rarely where an amount of hormone is produced that is sufficient to initiate culms but insufficient to promote flowering.

(a) excess water about the roots

(b) excess shade

(c) high humidity

(d) submergence

(e) abrupt changes in moisture, day length, or temperature

(f) insufficient vernalization

(4) True vivipary

\section{Viviparous Races}

Where the ranges of the viviparous races and related seminiferous forms overlap, the environment is not a primary cause of the manifestation of vivipary (Wycherley 1953). Wycherley considered the following British grasses exhibited a degree of constancy of vivipary (1) Festuca vivipara, (2) Poa bulbosa var. vivipara, (3) Poa alpina var. vivipara, (4) Poa jemtlandica, (5) Deschampsia caespitosa var. pseudalpina and (6) Deschampsia alpina. In addition to these British grasses genetic races have been recognized in (7) Festuca rubra, (8) Phleum pratense, (9) Poa arctica, (10) Poa sinaica and (11) Poa tolmatchewii.

Viviparous and seminiferous strains of Poa alpina were found by Muntzing (1940) to be morphologically similar and to have the same chromosome numbers $(2 n=26$ and 33 plus or minus 1); he suggested that in this case the character originated by mutation.

It is doubtful if studies of present day distribution (cf. Wycherley 1954) can indicate more than a north temperate or arctic-alpine origin for genetically controlled vivipary. Some pluvial or glacial period in the past must have intensified the conditions favorable to vivipary over a relatively long period of time and in this region species of Poa, Deschampsia, and Festuca would have made similar morphological responses to environment, a good example of epharmonic form. Flovik (1938) assumed that vivipary was relatively more common in the arctic flora than elsewhere owing to the combined action of hybridization, polyploidy, and extreme external conditions.

In Poa bulbosa and close relatives and in Phleum pratense 
there is an appearance of both bulbous bases of the culms and viviparous spikelets. There is a less direct association of the two characters in Arrhenatherum and Melica.

The genetically fixed taxonomic presence is overwhelmingly festucoid. Only in the case of Festuca vivipara has the presence of vivipary or proliferation been considered a characteristic indication of species formation and here the parameters of the species are not clear. However, unlike the genetic presence of variegated leaves which have been consistently described as forms, the tendencies to proliferation have been treated most frequently as varieties. According to Arber (1934) Festuca ovina in a normal sexual form is diploid, but in a type which has never been known to produce flowers is hexaploid. Forms in which proliferation was not altogether complete were intermediate as regards chromosomes ( 21 , triploid, or 28 tetraploid).

\section{Hybridization}

On the basis of chromosome morphology and numbers as well as the morphology of the glumes, Flovik (1938) suggested that Festuca vivipara on Spitzbergen was the hybrid $(2 \mathrm{n}=49)$ of an unreduced $F$. ovina var. brevifolia gamete $(\mathrm{n}=28)$ and a reduced $F$. rubra var. arenaria $(\mathrm{n}=$ 21) gamete. In Norway he visualized the reduced gametes of $F$. ovina $(\mathrm{n}=7)$ and $F$. rubra $(\mathrm{n}=21)$ giving rise to a fully viviparous fescue $(2 \mathrm{n}=28)$, which by means of an occasional flower (see Jenkin 1922) backcrosses with $F$. ovina yielding the seminiferous plant $(2 n=21)$. Jenkin and Thomas (1949) report weak seminiferous hybrids $(2 n=42)$ of $F$. ovina and F. rubra. Nanfeldt (1937) criticizes Flovik's hybridization schemes, because the general form and growth habit of $F$. vivipara is not intermediate between the supposed parents.

Poa $\mathrm{X}$ jemtlandica, in which non-viviparous specimens are not known, is considered to be a hybrid between $P$. alpina and $P$. flexuosa. Poa herjedalica is considered a hybrid between $P$. alpina and $P$. pratensis. Nygren (1949) suggested that the hybridization of forms with different life rhythms might be the origin of vivipary.

Flovik (1938) found Festuca ovina from Spitzbergen $(2 n=49)$ to have arisen through a cross between $F$. rubra var. arenaria $(2 \mathrm{n}=42)$ and $F$. ovina var. hrevifolia $(2 \mathrm{n}=28) . F$. ovina var. vivipara $(2 \mathrm{n}=28)$ from arctic Norway is regarded as having arisen from a cross between $F$. rubra var. arenaria $(2 \mathrm{n}=42)$ and $F$. ovina $(2 \mathrm{n}=14)$. A chromosomal basis for proliferation is also indicated by certain experiments in which spikes with proliferated spikelets occurred as a result of crossing wheats with 28 chromosomes with others having 42 (Biffen and Engledow 1926, according to Arber 1934).

\section{Polyploidy}

Turreson $(1930,1931)$ found that the normal, sexually reproducing Festuca ovina in Scandinavia was diploid $(2 \mathrm{n}=$ 14), whereas the viviparous forms were triploids and tetraploids and in one case hexaploid $(2 n=21,28$ or 42$)$. As vivipary was found to be most pronounced in the high polyploid forms Turreson suggested a relationship between polyploidy and vivipary. Flovik (1938) found viviparous Deschampsia alpina, Festuca ovina var. vivipara and Poa alpigena var. vivipara to be of allopolyploid origin.

\section{Malformation}

It is characteristic of the majority of those proliferating types which are not genetically controlled viviparous races, that they normally produce flower-bearing culms, but occasionally the spikelets in whole or in part of an inflorescence are proliferated. While these proliferations may produce new adult plants they do not inherit any tendency to proliferate under normal conditions.

\section{Mechanical Injury}

Sometimes this type of injury is self inflicted, for example if the sheathing leaves are too tight for the rapidly developing inflorescence to free itself. The resulting vegetative anomalies have been described as "contortions" (Martinez C. 1947).

\section{Pathology}

Aberrations due to pathological events are numerous and usually a re not related to vivipary, proliferation, or phyllody but they may cause changes which mimic them. Some are caused by rusts and smuts. Martinez C. (1945) reported abnormal spikelets in Bromus unioloides and Festuca hieronymi due to "algun insecto". Similar spikelets are common in Bromus marginatus in Wyoming. Molliard (1894) reported abnormal spikelets in Bromus secalinus caused by Phytoptus dubius, a mite. Martinez C. (1947) reported abnormal spikelets in Panicum dumissum parasitized by the pupa of diptera (a fly). Philipson (1937) found the outstanding effects of the nematode (Anguillina agrostis) in Agrostis tenuis are the unequal elongation of the glumes and the elongation of the lemma. These are only a few examples from a vast literature.

\section{Environment}

Viviparous races survive in areas and habitats where moist conditions prevail. Proliferation commonly occurs in autumn when the natural day length is decreasing and especially after a wet summer. According to Wycherley (1954) "humidity for these viviparous races is necessary for the establishment of plantlets, but not for the induction of the phenomenon." In Deschampsia caespitosa var. rhenana a submerged plant produced only proliferations while neighboring plants which had not been swamped bore flowers and fruit (Arber 1934).

Abrupt changes in environment have been thought to produce vivipary. In Cynosurus cristatus after long days had made some progress toward inflorescence initiation short days were applied and resulted in proliferation. In greenhouse to field transplants Wycherley (1954) indicated that insufficient vernalization may be a cause of proliferation.

\section{True Vivipary}

An embryo may germinate before the fall of the seed only if there is no dormancy. Pope (1940) induced this type of vivipary in barley by watering. According to Eyster (1931) such uninterrupted growth occurs in corn with defective endosperms. In corn Manglesdorf (1930) found that the tendency to premature germination, starting as early as the milk stage, was inheritable. Arber (1934) cites an example in Spartina townsendii. Wycherley (1953) illustrates an example in Festuca ovina.

While Poa sinaica is closely related to Poa bulbosa and produces basal bulbils, the var. vivipara of Tackholm from Mt. Sinai is based on "germinating in the panicle" which would indicate the condition of true vivipary.

\section{Annotated Species List}

Agropyron cristatum (L.) Gaertn. Reported by Piper (1921).

Agropyron repens. Beauv.

Reported by Wycherley (1954) as "ephemeral"proliferation and not a "viviparous race." 
Agrostis alba L. var. prolifera Aschers. and Graebn. Syn. Mitteleurop. Fl. 2:174. 1899

Reported by Duval-Jouve, 1871.

Agrostis alba L. var. vivipara Sweet, Hort. Brit. 443. 1826, nom. nud.

Agrostis canina L. var. vivipara Peterm. Fl. Lips. 83. 1838. Described from Germany.

Agrostis palustris Huds.

Diseased states caused by infection with Anguillina agrostis, (a nematode) have, according to Philipson (1937) been described as $A$. polymorpha var. vivipara Trin. Unifl. 200. 1824. and A. stolonifera var. vivipara Reichb. Agrost. Germ. 1:13. 1834. Other synonyms include A. sylvatica Huds., A. polymorpha var. sylvatica (Huds.) Gray and Vilfa alba var. sylvatica (Huds.) Gray

Agrostis stolonifera L.

Reported by Jan. \& Wacht. Nederl. Kruidk. Archief 50:113. 1940. as $A$. vulgaris var. stolonifera $\mathrm{m}$. vivipara and as $A$. stolonifera var. major $\mathrm{f}$. prolifera.

Agrostis tenuis Sibth.

Agrostis vulgaris var. vivipara Reichb. I. Agrost. Germ. 1:12. 1834. Characterized by Philipson, 1937, as a diseased state of $A$. tenuis Sibth.

Philipson (1937) further characterizes the following names as describing A. tenuis infected with Tilletia decipiens:

Agrostis pumila L. Mant. Pl. 1:31. 1767.

A. polymorpha Huds. var. pumila (L.) Huds. Fl. Angl. ed 2.31. 1778.

A. vulgaris With. var. pumila (L.) Pers. Syn. Pl. 1:75. 1805.

A. laxa Gray var. pumila Gray, Nat. Arr. Brit. Pl. 2:148, 1821

A. tenuis var. pumila (L.) Druce, List. Brit. Pl. 79. 1908.

A. capillaris Huds. var. pumila (L.) Druce, Fl. Oxfordsh. Ed. 2. 474. 1927.

Other synonymy of $\boldsymbol{A}$. tenuis Sibth included:

$A$. vulgaris var. vivipara Spenner, Fl. Friburg 1:93. 1825, from Germany.

A. vulgaris var. vivipara Opiz, Sezn. Rostl. Ceske 12. 1852, from Czechoslovakia.

A. vulgaris var. vivipara Parl. Fl. Ital. 1:183. 1848. from Italy.

A. vulgaris var. vivipara St. Lager, in Cariot, Etude des fleurs ed. 8. 2:902. 1889, from France.

Alopecurus pratensis L.

Reported by Wycherley (1954) as "ephemeral "proliferation and not a viviparous race."

Arrhenatherum avenaceum Beauv.

Mentioned by Arber (1934) cf. page 385 and reported by Wycherley, 1954 , as "ephemeral "proliferation and not a "viviparous race."

Avena sativa $\mathrm{L}$.

Reported by Duval-Jouve, 1871, and Nielsen (1941).

Briza subaristata Lam.

An example of "filodia" is reported by Martinez C. (1944).

Bromus inermis Leyss f. proliferus Louis-Marie, Rev. d'Oka 14:144. 1940. Also reported by Nielsen (1941).

Bromus macranthus Desv.

An example of "filodia" is reported by Martinez C. (1944).

Bromus purgans $\mathrm{L}$.

Reported by Nielsen (1941).

Bromus unioloides (Willd.) HBK)

Martinez (1945) reports malformation due to "algus insecto."

Coix lachryma-jobi $\mathrm{L}$.

Normally producing a spathe below the inflorescence, but in some cultivars this leaf-like structure is completely reformed above the maturing female.

Cynosurus cristatus $\mathrm{L}$.

var. viviparus Koel., Descr. Gram. 373. 1802.

var. viviparus S.F. Gray, Nat. Arr. Brit. Pl. 2:126. 1821.

var. viviparus Gus. Fl. Sic. Prodr. 1:88. 1927.

var. viviparus Lojac. Fl. Sicul. 3:333. 1909.

Reported by Wycherley (1954) as "ephemeral " and not a "viviprous race" and more frequent in autumn. Wycherley (1952) applied "short-day treatment" which resulted in a strong proliferation of the fertile spikelets also. Arber (1934) reports "In Cynosurus cristatus L. I have seen ${ }^{* * *}$ the sterile spikelets, which constantly accompany those that are fertile, may be prolonged so as to bear numerous leaves; in the spikelet drawn there were twenty-six. This sample from the Dog's-tailgrass, since it affects spikelets which are sterile even in the normal spike, indicates that spikelet-proliferation falls into place as a further stage in that sterilization process which we have already noticed in the normal reproductive shoot in the Gramineae. A special vegetative development in the inflorescence, which I have called the 'bouquet' abnormality, can also be illustrated from the Dog's-tail -grass; in this form, lateral axes, which are more or less naked, terminate in tufts of spikelets."

Cynosurus echinatus L.

Martinez C. (1945) reported "numerous casos de filodia de glumelas" in this annual. Penzig (1922) "anota casos de filodia para esta especie (sub viviparidad).

Cynosurus elegans Desv. var. viviparus Lojac, Fl. Sicul. 3:334. 1909. Described from Sicily.

Dactylis glomerata L.

f.m. vivipara Lange, Bot. Tidsskr. 188. 1877-1879, nom. nud., from Denmark.

var. vivipara Parl. Fl. Ital. 1:459. 1848, from Italy. Martinez C. (1947), reported both "filodia y proliferation." Arber (1934) reported the 'bouquet' effect. Wycherley (1954) reported an example as "ephemeral" and not a "viviparous race."

Deschampsia alpina (L.) R. \& S.

According to Lawrence (1945) "another close relative of $D$. caespitosa is D. alpina (L.) R. \& S., which differs in being viviparous and in occupying an ecologic zone to the north of caespitosa. ${ }^{* * *}$ is a hexaploid *** The high polyploidy and variation in chromonumber observed in alpina is characteristic of species that propagate asexually." D. alpina is of allopolyploid origin according to Flovik (1938).

D. caespitosa (L.) Beauv.

This species is characterized as non-viviparous by Lawrence (1945) but Nygren (1949) caused proliferation of spikelets in normal seminiferous Deschampsia caespitosa (L.) Beauv by shortday treatment. Both var. pseudalpina (Syme) Druce described in 1888 and var. rhenana Gren. described in 1872 have been used in reference to viviparous forms. Also reported by Duval-Jouve (1871).

Deschampsia caespitosa var. vivipara S.F. Gray, Nat. Arr. Brit. P1. 2: 137. 1821 described from Great Britain.

Deschampsia caespitsa var. vivipara Opiz, Sezn. Rostl. Ceske 37. 1852. nomen; Cheval. Fl. Envir. Paris ed. 2:806, 1861, described from France.

Deschampsia flexuosa (L.) Trin.

Stahlin (1929) found viviparous and non-viviparous plants to have the same chromosome number, $2 \mathrm{n}=28$.

Eleusine indica (L.) Gaertn.

Martinez Crovetto (1945) reports "filodia."

Eragrostis brizoides (L.f.) Nees

Bews (1918) illustrates (Fig. 23) E. brizoides showing vivipary which he says was common in several kinds of grasses during the wet season of 1917 in Africa.

Eragrostis capensis (Thumb.) Trin.

Eragrostis prolifera (Sw.) Steud.

A North American grass common on subtropical sandy beaches, the branches often fascicled, or developing extensive stolons with tufts of branches, suggesting the name "prolifera," the spikelets, however, apparently do not proliferate.

Eragrostis virescens Presl. Martinez C. (1945) found an example of "filodia de las glumelas."

Festuca alpina Suter. var. prolifera Schur. Enum. Fl. Transsilv. 785. 1866. Described in Rumania.

Festuca arundinacea L. f. m. vivipara Junge, Jahrb. Hamburg Wissenschaft Anstalt 22: Beih. 3, 66. 1905.

Described from Austria.

Festuca durisuscula var. vivipara Opiz, Lotus 3:182. 1853, nomen. Described from Austria.

Festuca fuegiana Hook. f. forma vivipara Hack. Engl. Bot. Jahrb. 6:247. 1885.

Festuca hieronymi Hack. Martinez C. (1945) reports a malformation due to "algun insecto."

Festuca obtusa Spreng. Reported by Nielsen, 1941.

Festuca purpurascens Banks et Sol. Martinez C. (1945) reports an example of "filodia."

Festuca ovina L.

See discussions under Festuca vivipara and Festuca rubra. 
Festuca rubra $\mathrm{L}$.

Flovik (1938) says viviparous Festuca ovina $(2 \mathrm{n}=49)$ from Spitsbergen arose through a cross between Festuca rubra var. arenaria $(2 \mathrm{n}=$ $42)$ and $F$. ovina var. brevifolia $(2 \mathrm{n}=28)$ Festuca ovina var. vivipara $(2 \mathrm{n}=28)$ from arctic Norway is a cross between $F$. rubra var. arenaria $(2 \mathrm{n}=42)$ and $F$. ovina $(2 \mathrm{n}=14)$.

Names used for viviparous $F$. rubra include:

Festuca rubra prolifera Piper, Contrib. U.S Nat. Herb. 10:21. 1906. F. rubra var. prolifera Piper, in Robinson, Rhodora 10:65. 1908.

F. prolifera (Piper) Fernald, Rhodora 35:133. 1933.

F. rubra var. subvillosa f. vivipara Eames, Rhodora 11:89. 1909.

F. rubra var. vivipara S.F. Gray, Nat. Arr. Brit. Pl. 2:122. 1821.

F. rubra var. vivipara Bluff \& Nees, Consp. Fl. Germ. ed. 2. 1:179. 1836 , nomen.

Wycherley (1954) reports an example of "ephemeral" proliferation and not a "viviparous race."

Festuca vivipara (L.) Sm. Fl. Brit. 1:114. 1800.

Festuca vivipara was first described by Ray (1690) in Synopsis Methodica Brittanicarum. London) as "spica foliacea."

According to Wycherley (1953) in Great Britain "the viviparous fescues are a group of asexually reproducing forms restricted in range by their method of propagation. It is useful ecologically and systematically to include all under one specific name." Turreson (1926, 1930, and 1931) found seminiferous amphimicts, viviparous apomicts, and intermediates he called ampho- apomicts. Howarth (1948) found vivipary in all known varieties of $F$. tenuifolia and $F$. ovina as well as in $F$. longifolia var. genuina. As Wycherley (1953) says, "the origin of $F$. vivipara is unknown, but its variation is certain." Flovik (1938) suggested that the different forms of Festuca vivipara are products of crossing between $F$. rubra and $F$. Ovina and therefore of allopolyploid origin.

The very complicated synonymy of these viviparous races including the following names:

F. ovina var. vivipara L. Sp. Pl. 73. 1753; ed. 2. 1:108. 1762.

F. ovina var. vivipara Huds. Fl. Angl. 36. 1762.

F. vivipara Hornem, Fl. Dan. 12 (fasc. 35); pl. 2043.1832.

F. ovina var. vivipara (Smith) Reichenb. Icon. Fl. Germ. Helv. 1:25. 1834.

F. ovina var. vivipara Hartm. Handb. Skand. Fl. ed. 4. 37. 1834.

F. ovina var. vivipara (Smith) Bab. Man. Brit. Bot. 372. 1843.

F. ovina var. vivipara (Hornem) Blytt, Norgess Fl. 143. 1861.

F. supina var. vivipara (L.) Richt. Pl. Eur. 1:93. 1890.

F. ovina subsp. eu-ovina var. supina subvar. vivipara Hack.

F. vivipara (L.) Sm. var. hirsuta (Lge.) Schd. in Devold \& Schol. Fl.

Pl. and Ferns of Southeast Greenland 140. 1933.

Festuca tenuifolia Sibth (including $F$. capillata Lam.)

Festuca trachyphylla (Hack.) Kruj. (including $F$. longifolia Thuill.)

F. longifolia var. trachyphylla (Hack.) Howarth

F. ovina var. duriuscula subvar. trachyphylla Hack.

$F$. tenuifolia Sibth. var. vivipara (Smith) Ducomm. Taschenb.

Hierochloe alpina R. \& S. var. vivipara Scheutz ex Fedtsch. Bull Jard. Bot.

Pierre le Grand 14 (Suppl. 2): 47. 1915, nomen.

Described from Russia.

Ichnanthus pallens (Sw.) Munro

Described by Fournier as "Panicum schlechtendalii monstrosum" in Mex. P1. 2: 31. 1886. Martinez (1945) reports the same occurrence, a multiplication of glumes and lemmas to give the appearance of species of Eragrostis, rather than the typical species of Ichnanthus with a single fertile floret.

Koeleria cristata (L.) Pers. var. vivipara Opiz, Seznam 56. 1852. nomen; Holuby, Oesteer. Bot. Zeitschr. 22:79. 1872.

Koeleria glauca var. typica f. vivipara Domin, Bibl. Bot. 65:56. 1907.

Koeleria gracilis f. vivipara Domin, Bibl. Bot. 65:181. pl. 2.f.7. 1907.

Koeleria phleoides (Vill.) Pers.

According to Martinez C. (1947) a case of "filodia."

Koeleria pyramidata (Lam. Domin, f. vivipara Domin. Bibl. Bot. 65:145. 1907.

Lolium multiflorum Lam.

According to Martinez (1947) "contorsion en el raquis y proliferacion y filodia en las espiguillas con diferentes grados de intensidad."

Lolium perenne L.f. vivipara Junge, Jahrb. Hamb. Wiss. Aust. 22 (Beih. 3): 68. 1905, without description, cf. f. viviparum Koch, Syn. ed. 2:956. 1844.

Also treated as a variety as follows:

var. viviparum Hein, Graeserfl. 136. 1877, from Europe. var. viviparum Mutel, Fl. Franc. 4:139. 1837, from France. var. viviparum S.F. Gray, Nat. Arr. Brit. Pl. 2:93. 1821, from Gt. Britain.

Wycherley, 1954, reports "ephemeral" proliferation, not a viviparous race; cf. Jenkin, 1922.

Melica papilionaceae $\mathbf{L}$.

Martinez C. (1945) reports "proliferation" and "tendenacia a la filodia."

Molinia coerulea var. vivipara Boenn. Prodr. Fl. Monas 28. 1824. Also treated as a variety as follows:

var. vivipara Blytt, Norges Flora 140. 1861.

var. vivipara Merino, Fl. Descr. Illustr. Galicia 3:319. 1909.

Panicum antidotale Retz.

The synonymy of this species includes Panicum proliferum Lam.

Tabl. Encycl. 4:747. 1798.

Panicum demissum Trin.

Martinez (1947) reports injury by dipterous flies.

Panicum virgatum $\mathrm{L}$.

Reported by Nielsen (1941).

Panicum viviparum Schumach. Beskr. Guin. Pl. 82. 1827. from Guinea, Africa.

Panicum viviparum Nees ex Steud. Syn. Pl. Glum. 1:97. 1854. also from Guinea, Africa.

Panicum viviparum Nees, Linnaea 8:57. 1883, in obs.

Paspalum proliferum Arech. Anal. Mus. Nax. Montevideo 1:63. 1894. Described from Uruguay.

Phalaris vivipara Pacluc. Fl. Marchig. 19. 1891, in syn of P. brachystachys Link.

Phleum boehmeri (L.) Wiebel var. vivipara Schur, Oestr. Bot. Zeitschr. 9":5/1859. refers to a var. of Phleum phleoides (L.) Karst.

Phleum pratense L. f. monstrosae

Phleum pratense L. f. proliferium Waisb. Magyar Bot. Lapok 4:66. 1905. Arber (1934) found timothy "near Cambridge, where these leafy 'spikes' are developed season after season; I have found them here in eight different years. The best time to look for them is between September and December. They illustrate the conservation of the outer empty glumes, which retain their normal character with sharing in the proliferation," (see page 385). Evans (1927) illustrated three types of proliferation (1) "proliferating florets, each having one bract enlarged to resemble a leaf. Either the pistil or stamens, or both are usually present." (2) Proliferous shoots, capable of developing directly into plants. In a proliferation of this type there are several leaflife parts, but no pistil or stamens." and (3) "spikelets with elongated rachilla."

Phleum pratense var. vivipara Schur, Oestr. Bot. Zeitschr. 9:15. 1859. from Rumania.

Phleum pratense var. viviparum S.F. Gray, Nat. Arr. Brit. Pl. 2:139. 1821, from Britton.

Phleum pratense f. viviparum (S.F. Gray) Iouis-Marie, Rev. d'Oka. 14:144. f. 10, no. 3. 1940.

According to Wycherley (1945) vivipary in Phleum pratense is "ephemeral" and not leading to a "viviparous race." Martinez C. (1945) describes a "torsion de la inflorescencia." Vivipary in Phleum is reported by Tourney (1891) and Nielsen (1941).

Poa

The sections suggested for Poa have not always been totally natural. For example Poa annua clearly does not belong in the \# Annuae but in the \# Pratenses with Poa pratensis. Nevertheless there appears to be a certain amount of natural grouping into sections of the viviparous species of Poa. These species have been treated variously in either \# Pratenses (\# Stoloniferae), \# Palustres, or \# alpinae.

$P$. alpigena (Fries) Lindm.

var. colpodea Th. Fries) Scholand. Vasc. pl. Svalb 89. 1934.

var. vivipara (Malmgr.) Scholand. Skriftom Svalbard og Ishavet 62: 88 f. 42.1934

Poa stricta subsp. colpodea Th. Fries in Ofvers. Vet. Ak. 26:138. 1869. Poa alpigena f. vivipara Malmgr. Ofvers. Vet. Ak. Forhandl.

Poa alpigena var. vivipara Hulten, Acta Univ. Lund. n. ser. 38: 198.

1942, from Norway.

Poa arctica var. vivipara (Malmgr.) Schol. ex Flovk, Hereditas 24: 24:516. 1938.

Poa alpigena var. vivipara is of allopolyploid origin according to Flovik (1938). 
Poa alpina L.

Poa bulbosa L. var. alpina Ascherson, Fl. Brand. 1:845. 1864.

Poa alpina var. vivipara L. Sp. Pl. 67. 1753, from Switzerland.

Poa vivipara (L.) Willd. Enum. Pl. Hort. Berol. 105. 1809.

Poa alpina var. vivipara (L.) S.F. Gray, Nat. Arriv. Brit. Pl. 2:105. 1821 , based on "Poa vivipara L." which was never described.

Poa alpina f. vivipara L. Sp. Pl. ed. W, In. p. 386, cf. Arber, 1934, page 385; cf. also Goebcl, 1905.

Poa alpina var. vivipara Bluff. Nees, Comp. Fl. Germ. ed. 2. 1:159. 1836.

Poa alpina var. vivipara Parnell, Grasses Brit. 212. pl. 94. 1845.

Poa alpina vivipara (Willd.) Scribn. \& Merr. Contr. U.S. Nat. Herb. 13:68. 1910.

In East Greeland this plant is common on solifluction soils (Bocher et al. 1968) and common along the entire Scandinavian mountain range (Nygren 1950).

This plant was described in preLinnaean literature by Schuechzer (1719). Stahlin (1929) found viviparous and non-viviparous plants to have the same chromosome number, 2 n -42 , but Nygren (1949) found varying numbers for both, between 31 and 57. For details on this species refer to Zollikofer (1930).

Poa annua L. var. vivipara S.F. Gray, Nat. Arr. Brit. P1. 2:106. 1821.

Poa annua L. var. vivipara Mutel, Fl. France 4:72. 1837

Poa arctica R.B.

P. arctica var. stricta (Lind.) Nannfeldt is viviparous according to Nygren (1950).

P. arctica var. vivipara Hooker, Fl. Bor. Amer. 2:246. 1840. cf. Hooker in Parry, Jour. Third. Voy. 206. 1826, nomen.

Poa arctica is very polymorphous in Scandinavia with chromosome numbers from 39 to 92 .

Poa bulbosa L.

Poa bulbosa var. vivipara Koel. Descr. Gram. in Gallia et Germania 189. 1802.

Paneion bulbosum var. viviparum (Koch.) Lunell, Amer. Midl. Nat. 4:222. 1915.

Poa bulbosa var. vivipara Koch. Fl. Syn. Germ. et. Helv. 802. 1837. Poa prolifera Schmidt in Mayer, Samml. Phys. Aufs. 1:188. 1791.

Poa crispa Thuill. La Flore des environs de Paris. ed. Il., 45. 1799.

Poa bulbosa spp. adulterina Aschers. \& Graebn. Syn. Mitteleur. Fl. 2:392. 1900 .

\section{P. bulbosa}

var. badensis (Haenke) Aschers. Fl. Brand. 1:845. 1864. based on Poa badensis Haenke, Baden, Austria.

subsp. badensis var. gelida (Schur) Achtaroff, Isv. Bulg. Bot. Drush. (Bull. Soc. Bot. Bulgaria) 8:128. 1959.

var. calciola Schur, Snum. Pl. Transsilv. 772. 1866. (from Rumania). spp. concinna Gaudin) Douin in Bonn. Fl. Compl. 12:29. 1927-1932.

based on Poa concinna Gaudin (Switzerland) also Hayek, Repert.

Sp. Nov. Fedde Beih. 50: 260. 1932.

ssp. eubulbosa var. concinna (Gaud.) Hayek, Fl. Balk. 3:260. 1932. var. concinna (Gaudin) Beck, Fl. Nieder-Osterr. 1:82. 1890.

spp. concinna var. thessala (Boiss. et Orph.) Achtaroff, Izv. Bulg. Bot. Druzh. (Bull. Soc. Bot. Bulgarie) 8: 129. 1939. Based on P. thesala Boiss. et.Orph. in Boiss, Diagn. 2. IV., p. 135., P. pumila Host var. thessala (Boiss. et. Orph.) Fl. Or., p. 605.

ssp. debilis Velen. Fl. Bulg. Suppl. 1:300. 1898. (Bulgaria) var. erubescens Schur, Enum. Pl. Transsilv. 772. 1886. (Rumania) ssp. eu-bulbosa Hayek, Fl. Balk 3:359. 1932.

var. typica Flori, Nuov. Fl. Anal. Ital. 1:128. 1923.

ssp. eubulbosa var. brizaeformis Trab. in Batt. \& Traub. FI

Alg. 207. 1895.

P. psammophila Schur. Enum. Transs. p. 773. 1866.

$P$. bulbosa var. psammophila (Schur) Asch. \& Graebn. Svn.

Mitteleur. Fl. 2:393. 1900. (Rumania)

Poa badensis Haenke spp. psammophila (Schur) Nyar, Bulet. Grad. Bot. Cluj 11:40. 1951.

Poa bulbosa var. glabriflora Roshev. in Fedtsch. Fl. Turkm. 1:143. 1932, in Russian.

ssp. leucoglossa Velen. Fl. Bulg. Supply. 1:300. 1898. (Bulgaria) var. normalis Trautv. Acta Hort. Petrop. 7:524. 1881. (Russia) var. nuda Somm. \& Lev. Acta Hort. Petrop. 16:452. 1900. (Russia) var. praecox (Borb.) Richt. Fl. Eur. 1:85. 1890.

Based on Poa praecox Borb. Oesterr. Bot. Zeitschur. 28:135. 1878. var. prolifera K. Gmel. Fl. Badens. 1:194. 1805 (Germany) var. prolifera Schur, Enum. P1. Transsilv. 772. 1866 (Czechoslovakia)

ssp. pseudoconcinna (Schur) Domina, Acta Bot. Bohem. 11:31. 1936.

Based on P. pseudo-concinna Schur. Enum. Transsilv. 773. 1866. var. pseudoconcinna (Schur) Beck, Wiss. Mitt. Bosn. Herzog 9:444. 1904.

Poa bulbosa Rasse II. pseudoconcinna (Schur.) Aschers. \& Graebn. Sym. Fl. 2:392. 1900, based on $P$. pseudoconcinna seu. P. protuberata Schur

Poa bulbosa ssp. timoleontis (Heldr.) Bornm. Beih. Bot. Centralbl. Abt. II. 26:437. 1910. Based on P. timoleontis Heldr. (Greece) var. umbrosa Schur, Enum. P1. Transsilv. 772.1866 (Rumania) var. verticillata Coss. \& Germ. Fl. Env. Paris 2:642. 1845. (France) var. vivipara Koel. Descr. Gram. 189. 1802. (Europe)

(same combination made many other times but all of later date)

In pre-Linnaean literature Poa bulbosa var. vivipara was described by Bauhin (1620), by Tournefort (1700) and by Scheuchzer (1719). Akerberg (1942) gives the chromosome numbers of Poa bulbosa (seminiferous) as $2 n=28$ and 45 . Tutin (1952) mentions for the viviparous plant $2 n=35$. When normal lemmas are pubescent their proliferated counterparts may be glabrous.

Poa cusickii Vasey

Herbarium specimen seen; probably insect damage.

Poa herjedalica H. Smith, Veg. Utvecklingshist. Centralsvensk. (NorrlandsktHandbibl. 9): 150. 1920. From Sweden.

According to Nygren (1950) "the hybrid between Poa alpina and Poa pratensis alpigena, named Poa herjedalica by Smith in 1920, plays a rather great role in the plant communities of the northern Scandinavian mountain range. ${ }^{* * * * * * * * *}$ three different complexes of viviparous Poa forms occur in the Scandinavian mountains. For the first, the complex of viviparous Poa alpina, for the second that of the viviparous Poa pratensis alpigena, and for the third that of Poa herjedalica which bridges the two other complexes, by which all three complexes form a long series with transitional forms."

Poa iridifolia Hauman, Anal. Mus. Nac. Hist. Nat. Buenos Aires 29:407, pl. 1. 1917.

A case of "filodia" reported by Martinez C. (1945)

Poa jemtlandica (Almq.) Richt. PI. Eur. 1:84. 1890.

P. alpina subsp. jemtlandica Almq. Bot. Centralb. 14:320. 1883.

According to Nygren (1950) "up to now a single hybrid combination is known for Poa laxa flexuosa, viz. the hybrid Poa alpina vivipara which occurs in Scandinavia as well as in Scotland, but which has not hitherto been found on Iceland. For many reasons this hybrid is assumed to have originated only once, and therefore it must be supposed to be very old (cf. Smith, 1920, Nannfeldt, 1937). $P$. jemtlandica is morphologically uniform all over its entire distribution area and has the chromosome number $2 \mathrm{n}=37$ in Scandinavia, which means that a reduced female gamete with 21 chromosomes from flexuosa should have fused with a male gamete with 16 chromosomes from viviparous alpina."

Poa laxa Haenke var. flexuosa (Smith) Hartm. Handb. Skand. Fl. 57. 1820. Said to be one of the parents of the hybrid $P$. jemtlandica

Poa laxa Haenke var. vivipara S.F. Gray, Nat. Arr. Brit. Pl. 2:106. 1821.

Poa laxa Henke var. vivipara Anderss. Fl. Scand. Gram. 45. 1852.

Poa pratensis $\mathrm{L}$.

var. alpigena Blytt. Norgas Fl. 130. 1861.

According to Nygren (1950) viviparous races occur.

var. colpodea (Th.Fr.) Schol. based on Poa colpodea T. Fries.

Ofv. Svensk. Vet. Akad. Förh. 26: 138. 1869. A viviparous plant with

$2 n-35$ or 35 plus 4, occurs in Greenland (Bocher et al. 1968.)

var. prolifera Ostenf. Meddel. Grland 64:197. 1923. nomen.

cf. Ostenf. op. cit. 68:9. 1926.

var. vivipara Huds. Fl. Angl. ed. 2. 39. 1778, from Wales.

Poa sinaica Steud.

$P$. sinaica var. vivipara V. Tackh. in V. \& G. Tackholm, Flora of Egypt, Egypt. Univ. Faculty Sci. Bull. no. 17: 172. 1941.

"spikelets violet-flushed (in type green) germinating in the panicle (in typc not)."

Poa sublanata Reverd. A variety vivipara Tzvel. was described in 1964.

Poa tolmatchewii Roshev.

The variety stricta (Lindeb.) Tzvel. includes as snynonyms $P$. arctica ssp. stricta (Lindeb.) Nannf., $P$. artica var. stricta (Lindeb.) Hyl., $P$. 
stricta Lindeb. and $P$. artica var. vivipara auct.

Poa trivialis $\mathrm{L}$.

According to Wycherley (1954) who quotes Jenkin (1922), prolifery observed "in greenhouse or experimental conditions" and therefore "ephemeral" and not leading to a "viviparous race ."

Scleropogon brevifolius Phil.

Herbarium specimen seen, probably a case of insect damage.

Sorghum

Arber (1934) reports Laude, H.H. and F.C. Gates (1929): "one of the extremest instances of proliferation, which have been described, is a sterile head of Sorghum, in which the lower spikelet of each pair bore, in succession to the outer glumes, a series of as many as 28 to 41 scaleleaves closely inserted on the spikelet axis."

Zea mays $\mathrm{L}$.

According to Eyster (1931) "vivipary, the continuous development of the sporophyte in maise, is determined by genetic factors and is strongly influenced in its expression by environmental factors." $\mathrm{He}$ says further that "vivipary is regarded as a primitive plant character which, by the interaction of genetic factors and unfavorable growth conditions, may be inhibited," leading to the advanced character dormancy which enables survival through unfavorable growth conditions.

\section{Bibliography}

Akerberg, E. 1942. Cytogenetic studies in Poa pratensis and its hybrid with Poa alpina. Hereditas 28:1.

Arber, Agnes. 1934. The Gramineae. Cambridge Univ. Press 1-480.

Bews, J.W. 1918. The grasses and grasslands of South Africa. Pietermaritzburg 1-337.

Blaringhem, L. 1908. Mutation et traumatismes. Etude sur l'evolution des formes vegetales. Diss. Paris. 1-248.

Bocher, T., Holmen, K., and K. Jakobsen. 1968 Flora of Greenland. $1-312$.

Chabert, A. 1896. Le viviparisme. Bull. Herb. Boiss, 4:229-232.

Cooper, J.P. 1951. Studies on growth and development of Lolium. II. Pattern of bud development of the shoot apex and its ecological significance. J. Ecol. 39:228.

Duval-Jouve, J. 1871. Étude anatomique de l'arête des gramineés. Mém. Acad. Sci. et Lettres de Montpellier 53-78.

Evans, M.W. 1927. The life history of timothy. U.S.D.A. Bull. 1450: 1-56.

Exo, A. 1916. Poa alpina und die Erscheinung der Viviparie bei ihr. Diss. Bonn.

Eyster, W.Y. 1931. Vivipary in maize. Genetics. 16: 574-590

Flovik, K. 1938. Cytological Studies of Arctic grasses. Hereditas 24: 265376.

Galinat, W.C., and A.W. Naylor. 1951. Relation of photoperiod to inflorescence proliferation in Zea mays L. Amer. J. Bot. 38: 38.

Goebel, K.E. 1900-1905. Organography of plants. Trans. by I.B. Balfour 2 vols., illus. Oxford.

Halperin, M. 1931. The occurrence of normal (unproliferated) florets in Poa bulbosa in the United States. J. Amer. Soc. Agron. 23: 511-515.

Halperin, M. 1931. A taxonomic study of Poa bulbosa L. Univ. of Calif. Publics. in Botany 16: 171-183.

Halperin, M. 1933. The taxonomy and morphology of bulbous bluegrass, Poa bulbosa vivipara. J. Amer. Soc. Agron. 25: 408-413.

Harris, J.A. 1912. Chloranthy and vivipary in the staminate inflorescence of Euchlaena mexicana. Torreya 12: 181-183.

Hopkirk, T. 1817. Flora anomala. A general view of the anomalies in the vegetable kingdom. Glasgow.

Howarth, W.0. 1925. On the occurrence and distribution of Festuca ovina L. sens. ampl. in Britain. J. Linn. Soc. Bot. 47: 29.

Howarth, W.0. 1948. A synopsis of British fescues. Rep. Bot. Soc. \& Exch. Club Brit. 13: 338-346.

Hunger, E.H. Ueber vivipare pflanzen und die Erscheinun der apogamie. Diss. Bautzen.

Jenkin, T.J. 1922. Notes on vivipary in Festuca ovina. Bot. Soc. and Esch. Club. illus. Brit. Isles Rept. 1921: 418-432.

Karper, R.E., and J.C. Stephens. 1936. Floral abnormalities in Sorghum. Jour. Hered. 27: 183-194.

Kennedy, P.B. 1929. Proliferation in Poa bulbosa. J. Amer. Soc. Agron. 21: $80-91$.

Khan, R. 1950. Proliferation and some other abnormalities in the inflorescences of some grasses. Indian Bot. Soc. J. 29: 119-126.

Kostoff, D. 1940. A case of vivipary in rye. Curr. Sci. 9: 279.

Kunzel, Wilh. 1916. Ueber die viviparie der graser. Zeitscher fur Planzenkrankheiten 26 Band, 1: 285-291.
Laude, H.H. and F.C. Gates. 1929. A head of Sorghum with greatly proliferated spikelets. Bot. Gaz. 88: 447-450.

Lawrence, W.E. 1945. Some ecotypic relations of Deschampsia caespitosa. Amer. J. Bot. 32: 298-314.

Lillie, R.S. 1918. Heredity from the physico-chemical point of view. Biol. Bull. 34: 65-90.

Mangelsdorf, P.C. The inheritance of dormancy and premature germination in maize. Genetics 14: 462-494.

Martinez Crovetto, R. 1944. Algunos casos teratológicos en Gramíneas. Rev. Arg. Agr. 11: 106-115.

Martinez Crovetto, R. 1945. Nuevos casos teratoloogicos en Gramíneas. Darwiniana 7: 91-102.

Martinez Crovetto, R. 1947. Algunos casos teratológicos en Gramíneas. 2. Darwiniana 7: 346-358.

Masters, M.T. 1862. On proliferation in flowers and specially on the kind termed axillary prolification. Trans. Linn. Soc. 23: 481-493.

Masters, M.T. 1864. A description of some remarkable malformations affecting the genus Lolium. J. Proc. Linn. Soc. 7: 121-124.

Masters, M.T. 1869. Vegetable teratology. An account of the principal deviation of the usual construction of plants. London.

Molliard, M. 1894. Sur les modifications produites dans les epillets du Bromus secalinus infeste par le Phytopus dubius. Nat. Bull. Soc. Bot. France 41: 430-433.

Muntzing, A. 1940. Further studies on apomixis and sexuality in Poa. Hereditas, Lund, 26: 115-

Nanfeldt, J.A. 1937. On Poa jemtlandica (Almqu) Richt., its distribution and possible origin. A criticism of the theory of hybridization as the cause of vivipary. Bot. Not. 1937: 1-27.

Nannfeldt, J.A. 1940. On the polymorphy of Poa arctica. R. Br. Symb. Bot. Upsalienses $4: 1$.

Nielsen, G. 1941. Grass studies V. Observation on proliferation. Bot. Gaz. 103: 177-181.

Nygren, A. 1949. Studies on vivipary in the genus Deschampsia. Hereditas 34: 27-32.

Nygren A. 1950. Cytological and embryological studies in Arctic Poae. Symb. Bot. Upsalienses 10: 1-64., illus.

Penzig, 0. 1922. Pflanzen teratologie systematisch geordmet. Tomo 3. Berlin.

Philipson, W.R. 1934. Morphology of the grass lemmas. New Phytol. 33: 359.

Philipson, W.R. 1935. Abnormal spikelets in the genus Agrostis L. J. Bot. 73: 65.

Piper, C.V. 1924. Bulbous bluegrass (Poa bulbosa L.). Torreya 24: 7-8. J. Hered. 12: 423., illus.

Piper, C.V. 1924. Bulbous bluetgrass (Poa bulbosa L.). Torreya 24: 7-8.

Pope, M.N. 1949. Viviparous growth in immature barley kernels J. Agr. Res. 78:295.

Riddelsdell, H.J. 1907. Poa bulbosa L.f. vivipara (note). Rep. Bot. Exch. Club. 2: 250.

Scheuchzer, J. 1719. Agrostographia sive Graminum, Juncorum, Cyperosum, Cyperoidum, usque, affinium Historia 211-212.

Stahlin, A. 1929. Morphologishe und zytologische Untersuchugen an Gramineen. Wirs. Ardiv. of Landiv., A. Pflanzenbau 1: 330-398.

Thoenes, H. 1939. Morphologie und anatomie von Cynosurus cristatus und die Erscheinungen der viviparie bei ihm. Bot. Archiv. Bd 25: 284.

Toumey, J.W. 1891. Peculiar forms of proliferation in timothy. Bot. Gaz. 16: 346-347.

Turesson, G. 1926. Studien uber Festuca ovina L. 1926. I. Normalgeschlechtliche, halbund ganzvivipare typen nordischer Herkunft. Hereditas 8: 161-206.

II. Chromosomenzahl and viviparie. Hereditas 13: 177-184. 1930. III. Weitere Beitrage zur kenntnis der Chromosomenzahlen viviparer Formen. Hereditas 15: 13-16. 1931.

Tutin, T.G. 1952. in Clapham, A.R. Tutin, T.G. \& E.F. Warburg. Flora of the British Isles. Cambridge.

Wakker, J.H. 1891. Viviparie bij Grassen. Ned. Kruidk Archief 681-682.

Wycherley, P.R. 1952. Temperature and photoperiod in relation to flowering in three perennial grass species. Meded. van de I andb. Te Wageningen/Nederland 52: 75-92.

Wycherley, P.R. 1953. Proliferation of spikelets in British Grasses. I. The taxonomy of the viviparous races. Watsonia 3: 41-56.

Wycherley, P.R. 1953. The distribution of the viviparous grasses in Great Britain. J. Ecol. 41: 275-288.

Wycherley, P.R. 1954. Vegetative proliferation of floral spikelets in British Grasses. Ann. of Bot. n.s. 18 (69): 19-127.

Zollikofer, Clara. 1930. Zur Fortpflanzung von Poa alpina L. Jahrbuches der St. Gallischen Naturw. Gesellschaft. Vol. 65 (1929 and 1930):99-117. 